\title{
Research of Chosen Acoustics Descriptors of Developed Materials from Old Automobile Recycled Materials ${ }^{\dagger}$
}

\author{
Miroslav Badida, Lydia Sobotova *, Anna Badidova, Marek Moravec and Alzbeta Mikulova \\ Department of Process and Environmental Engineering, Institute of the Design and Process Engineering, \\ Faculty of Mechanical Engineering, Technical University of Kosice, Letna 9, 04200 Kosice, Slovakia; \\ miroslav.badida@tuke.sk (M.B.); anna.badidova@tuke.sk (A.B.); marek.moravec@tuke.sk (M.M.); \\ alzbeta.mikulova@tuke.sk (A.M.) \\ * Correspondence: lydia.sobotova@tuke.sk; Tel.: +421-55-602-2793 \\ + In Proceedings of the 6th International Conference Quo Vadis Recycling, High Tatras, Slovakia, 6-9 June 2017.
}

Received: 26 April 2018; Accepted: 11 June 2018; Published: 14 June 2018

Abstract: Legislative regulations and standards have been approved for noise control, aimed at controlling noise minimization. This problem is also under the public interest, because noise is increasing in many counties. EU directive 70/157/eec determines and controls limits of environmental noise and is aimed at creating less noisy and more pleasant outdoor and indoor environments for European residents within "sustainable development in Europe". This study focused on the utilization of new, so-called acoustic more convenient materials, based on and produced from old materials from automobiles, e.g. foam, textile, rubber, and tires. The chosen acoustic parameters - sound absorption coefficient and sound transmission loss-of these materials were tested, and the acoustic properties of materials were subsequently improved compared to tested values and potential applications for them were found.

Keywords: noise; transportation; sound absorption coefficient; sound reduction index

\section{Introduction}

The negative effects of environmental noise are various and can be caused by many different sources of noise. According to EU directive 70/157/eec [1] and the World Health Organization (WHO) [2], there are approximately 80 million people in the European Union exposed to high noise levels. It is unacceptable in the long term. There are 170 million people living in so-called "gray areas" that are characterized by the permanent production of annoying noise [3-5].

The significant source of noise is transport (road, rail and air) while the dominant source is road traffic [6,7]. The problem of road traffic noise is often tackled through the construction of noise barriers [7-9] from various absorbing and reflective materials. There are several research teams dealing with the research of acoustic materials [9-11].

This paper presents the results of scientific and research activities focusing on the development and study of acoustically suitable materials based on recycled components from vehicles after the expiry of their life cycle [12-14]. The results obtained by measuring selected acoustic parameters (the sound absorption coefficient $(\alpha)$ and the reduction index $\mathrm{R}$ ) are presented $[15,16]$. 


\section{Measurement of Selected Acoustic Parameters of the Acoustic Materials under Development}

The following acoustic parameters were chosen from several possible acoustic descriptors:

- $\quad$ the reduction index $\mathrm{R}$; and

- $\quad$ the sound absorption coefficient $(\alpha)$.

The sound absorption coefficient $(\alpha)$ and the reduction index R can be measured by two methods:

- the standing wave ratio method; and

- the transfer function method.

The transfer function measurement method was utilized. This method can be used for measuring the sound absorption coefficient, the reflection factor, the normal impedance and the normal admittance [17-20].

Figure 1 shows an impedance tube based on the transfer function method.

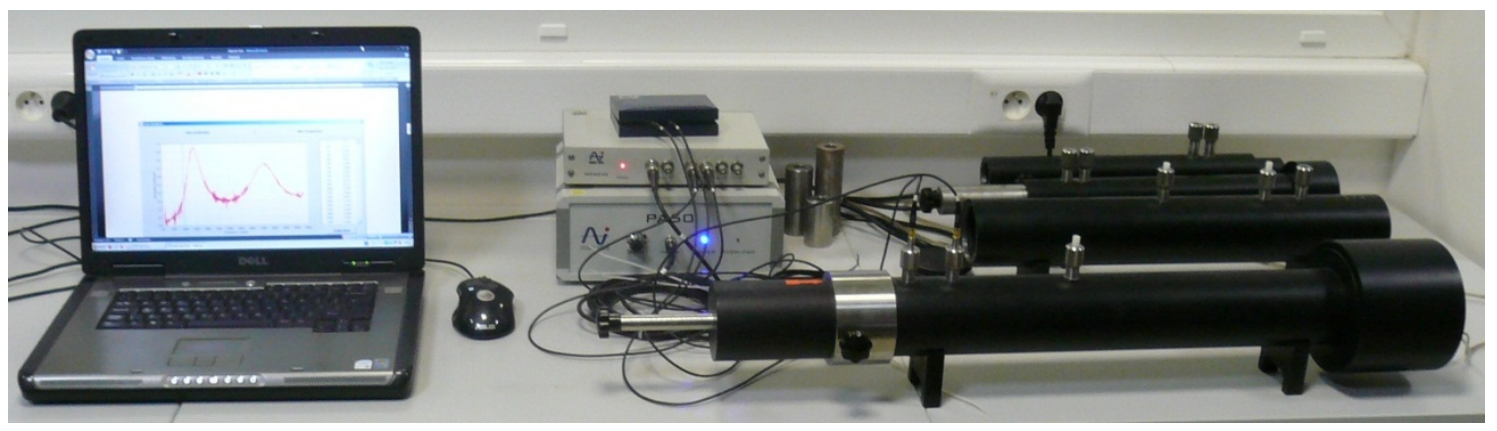

Figure 1. Kundt tube.

The proposed measuring methodology includes the utilization of a Kundt tube with two positions of the positioning microphones and the system of numerical frequency analysis for the determination of normal incidence sound absorption coefficient of sound absorbers. It can be applied for the determination of the acoustic surface impedance or acoustic surface admittance for the sound absorbing materials. The impedance ratios of sound absorbing materials are proportional to their physical properties, such as airflow resistance, elasticity, porosity and density.

In compliance with STN EN ISO 10534-1 standard, the proposed test method utilizes an impedance tube with a sound source connected to one end and a test specimen mounted in the tube on the other end. This test method is an alternative measurement method, which is, in general, much faster than the method included in STN EN ISO 10534-1 [21-24].

The measurement of the absolute and transmission characteristics of the developed acoustic materials are used by researchers for the acoustic design of devices such as automobiles, household appliances, etc.

\section{Measurement of Chosen Acoustic Parameters of Developed Acoustically Suitable Materials}

The proposed measurement methodology was verified by experimental tests with newly developed materials (Ekomolitan and recycled rubber). The experimental tests included the measurements of acoustic parameters, namely the sound absorption coefficient $(\alpha)$ and the reduction index $\mathrm{R}$ for the tested materials.

The experimental research tests were designed and verified at the Department of Process and Environmental Engineering, Faculty of Mechanical Engineering, Technical University of Kosice, Kosice, Slovakia. 


\subsection{The Hardware and Software Equipment Used}

The architecture of hardware equipment used for measuring the sound absorption coefficient $(\alpha)$ (for the frequency bands $100-800 \mathrm{~Hz}$ and $400-2500 \mathrm{~Hz}$ ) is shown in Figure 2.

The measured system includes the tube with the inner diameter of $60 \mathrm{~mm}$ (marked as SW060-L) and the holder of the tested sample with the inner diameter of $60 \mathrm{~mm}$ (marked as SW060-S).

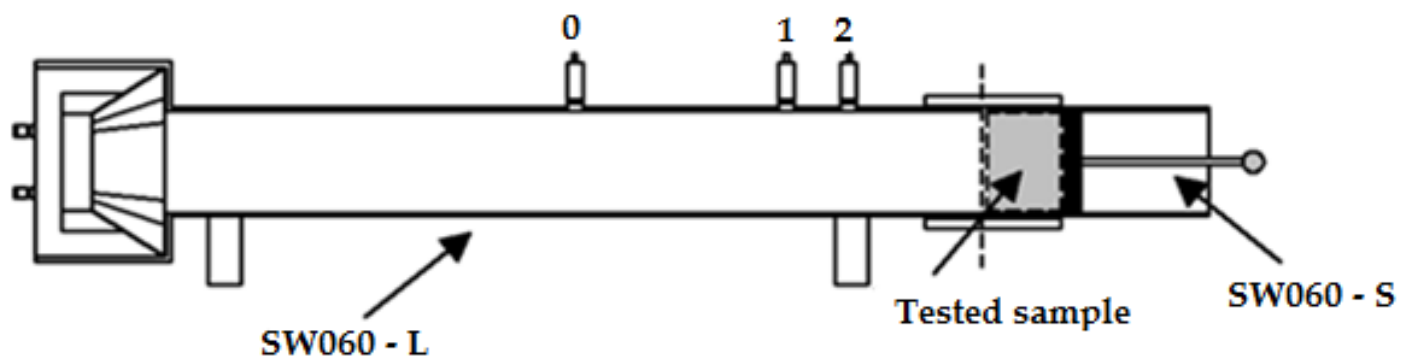

Figure 2. The sound absorption coefficient $(\alpha)$ system measured: 0,1 , and 2 are the mounting places for microphone sockets.

The system for measuring of the reduction index $\mathrm{R}$ (for the frequency bands $100-800 \mathrm{~Hz}$ and $400-2500 \mathrm{~Hz}$ ) is shown in Figure 3. Similarly, the measured system consists of the tube with the inner diameter of $60 \mathrm{~mm}$ (marked as SW060-L) and of the tube extension piece with the inner diameter of $60 \mathrm{~mm}$ (marked as SW060-E).

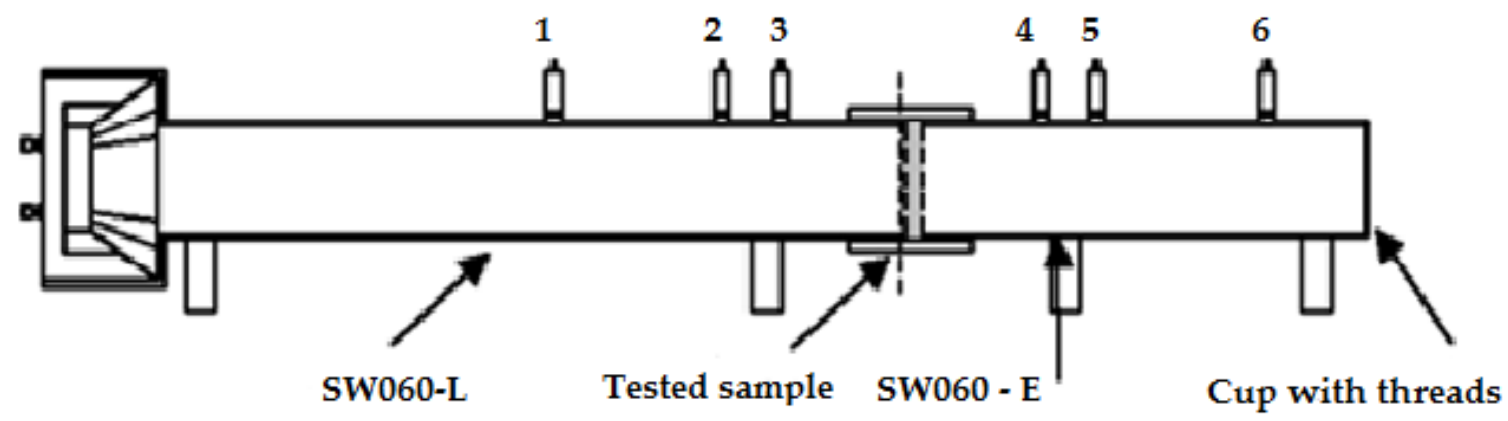

Figure 3. The reduction index $\mathrm{R}$ system measured: $0,1,2,3,4$, and 5 are the mounting places for microphone sockets.

\subsection{The Experimental Materials Used in Testing}

For experimental measurements, materials from selected components of vehicles after the expiry of their life cycle were used. Materials tested were recycled by operations such as crushing, cutting, grinding, heating, stamping, etc.

Specifically, the following materials were used.

- Ekomolitan (Figures 4 and 5): The material was manufactured by the recycling of a pure polyurethane foam (PUR foam) from seats taken from old vehicles by adhesive-free hot pressing of the recycled PUR products technology:

Ground fraction: $2.00-10 \mathrm{~mm}$;

Pressing at $200{ }^{\circ} \mathrm{C}$ (Steaming by superheated steam);

Pressing pressure: $5.7 \mathrm{kPa}$;

Hold time under the pressure at given temperature: $12 \mathrm{~min}$;

Pressed piece density: $1.2 \mathrm{~g} \cdot \mathrm{cm}^{-3}$ 
Figure 4 shows the specimens of the PUR foam ground fraction. Figure 5 shows the result after pressing, i.e., Ekomolitan foam.

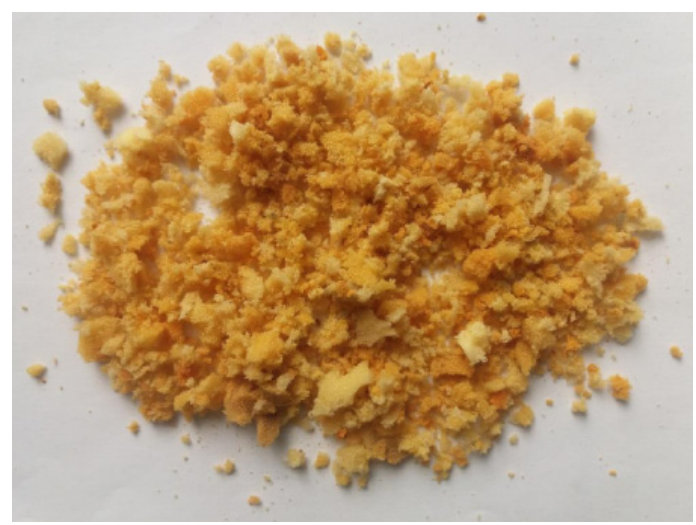

Figure 4. Ground fraction of PUR foam.

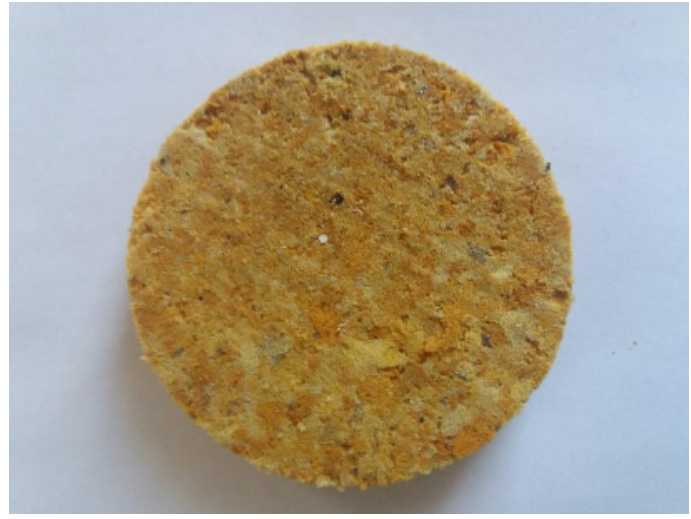

Figure 5. Ekomolitan after pressing.

- Recycled rubber (Figures 6 and 7): It is the product of the process of recycling used tires. To produce sound-absorbing material, the rubber sawdust, rubber cords and rubber grinding layer from tire retreading is suitable. The mono-structural material is most often produced from a rubber fraction. The technical material selected:

Ground fraction: $4-6 \mathrm{~mm}$;

$\bigcirc \quad$ Pressing temperature: $900-1200^{\circ} \mathrm{C}$;

$\bigcirc \quad$ pressing pressure: $20.265 \mathrm{bar}=2.0265 \mathrm{MPa}$;

$\bigcirc \quad$ Hold time under the pressure at given temperature: $12-15 \mathrm{~min}$;

Pressed piece density: $1.65 \mathrm{~g} \cdot \mathrm{cm}^{-3}$

The author of this paper filed patent application No. 1/288237 [8] dealing with the production of this sound-absorbing material. 


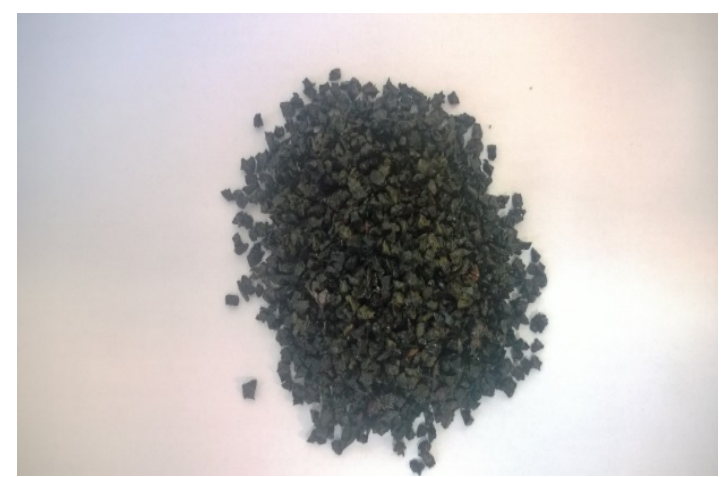

Figure 6. Ground Fraction of Recycled Rubber.

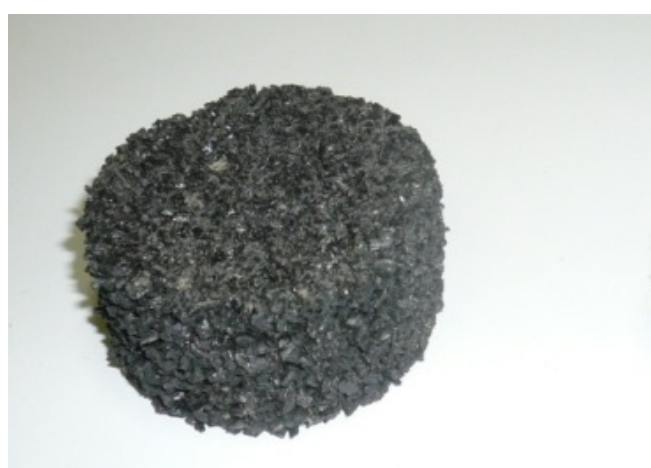

Figure 7. Recycled rubber after pressing.

- $\quad$ Nobasil (Figure 8): Material was manufactured from mineral fibers (bead wool) bonded by a modified artificial resin with the addition of hydrophobic and antifungal substances. The material is sewn on one side by glass thread with stitches fastened with glue onto a lightweight glass fiber mat.

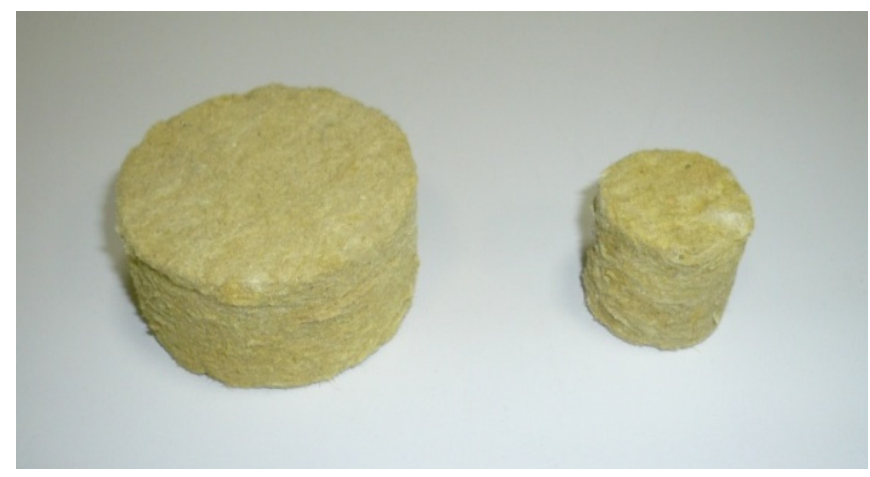

Figure 8. Nobasil from mineral fibers.

This material has wide application in civil engineering owing to its good thermal-insulation and sound-absorbing properties. The material has been used in comparisons with newly developed material properties. Nobasil is often used as one of the materials in noise barrier sandwich construction.

\subsection{Preparation of Test Samples}

Three materials, including their combinations, were used for the preparation of the test samples (Ekomolitan, recycled rubber and Nobasil). The specific examples are shown in Figure 9. 
The test samples had diameters of $30 \mathrm{~mm}$ and $60 \mathrm{~mm}$. The samples had thicknesses of $20 \mathrm{~mm}$, $30 \mathrm{~mm}, 40 \mathrm{~mm}, 50 \mathrm{~mm}$ and $60 \mathrm{~mm}$.

1) single - layer samples

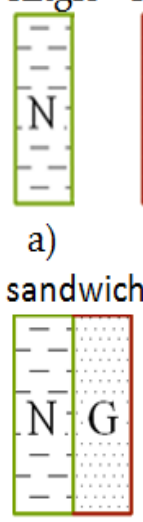

a)

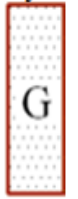

b)

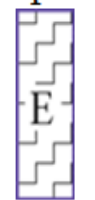

c)

2) sandwich samples - two - layer samples

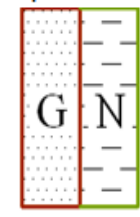

b)

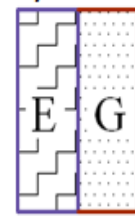

c)

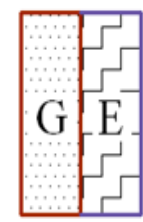

d)

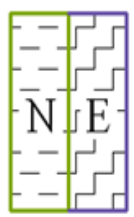

e)

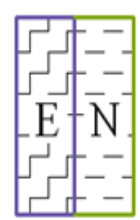

f)

3) three - layer samples

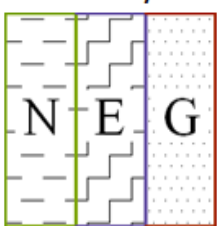

a)

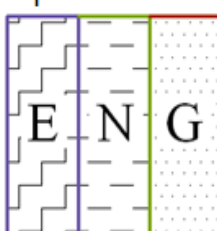

b)

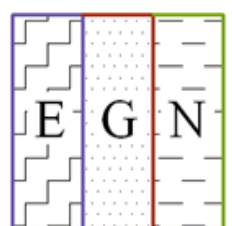

c)

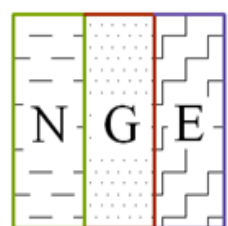

d)

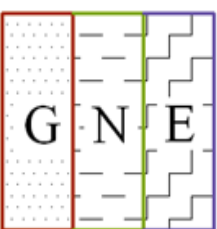

e)



f)

Figure 9. Test samples: N—Nobasil; E-Ekomolitan; G—Recycled Rubber.

\section{The Results of Experimental Measurements}

The sound absorption coefficient $(\alpha)$ is a dimensionless number ranging from 0 to 1 . The closer the measured value is to 1 (or if it is equal to 1), the better (higher) is the sound absorption of the measured material (absorber).

The reduction index $\mathrm{R}$ was also measured in the experiment. This is the value given in " $\mathrm{dB}^{\text {" based }}$ on the ratio of the wave of incident sound to the front side of the acoustically absorbing material to the sound waves transmitted from the rear side. The reduction index $\mathrm{R}$ represents the damping properties of the material, i.e., the is higher value, the more muffled is the sound.

Many measurements of the sound absorption coefficient $(\alpha)$ and reduction index $\mathrm{R}$ were made for homogeneous material (Ekomolitan, recycled rubber, or Nobasil) and for two- and three-layered sandwich structures with various thickness.

The values obtained for the sound absorption coefficients of the materials with a thickness of $60 \mathrm{~mm}$ are given in Table 1, where red numbers mean the worst values of the parameters obtained from the materials measured and green numbers mean the best values of the parameters obtained from materials measured.

The reduction index $\mathrm{R}$ values for materials with thickness of $60 \mathrm{~mm}$ are shown in Table 2, where red numbers mean the worst values of the parameters obtained from materials measured and green numbers mean the best values of the parameters obtained from the materials measured.

The values for materials with thickness of $20 \mathrm{~mm}, 30 \mathrm{~mm}, 40 \mathrm{~mm}$, and $50 \mathrm{~mm}$ [9] were obtained similarly.

The results of measurements of the sound absorption $(\alpha)$ of the homogeneous material (Ekomolitan, recycled rubber, and Nobasil) with thickness of $60 \mathrm{~mm}$ are shown in Figure 10.

The results of the reduction index $\mathrm{R}$ measurements of $60-\mathrm{mm}$-thick homogeneous materials are shown in Figure 11. 
Table 1. Sound absorption coefficient values for materials with thickness of $60 \mathrm{~mm}$.

\begin{tabular}{|c|c|c|c|c|c|c|c|c|c|}
\hline \multirow[b]{2}{*}{$\begin{array}{c}\text { Frequency } \mathrm{f} \\
{[\mathrm{Hz}]}\end{array}$} & \multicolumn{9}{|c|}{ The Sound Absorption Coefficient $\alpha[-]$} \\
\hline & Ekomolitan & $\begin{array}{l}\text { Recycled } \\
\text { Rubber }\end{array}$ & Nobasil & $\begin{array}{c}\text { Recycled Rubber } \\
+ \text { Ekomolitan + } \\
\text { Nobasil }\end{array}$ & $\begin{array}{l}\text { Recycled Rubber } \\
\text { + Nobasil + } \\
\text { Ekomolitan }\end{array}$ & $\begin{array}{c}\text { Nobasil + } \\
\text { Recycled Rubber } \\
\text { + Ekomolitan }\end{array}$ & $\begin{array}{c}\text { Ekomolitan + } \\
\text { Recycled Rubber } \\
\text { + Nobasil }\end{array}$ & $\begin{array}{c}\text { Ekomolitan + } \\
\text { Nobasil + } \\
\text { Recycled Rubber }\end{array}$ & $\begin{array}{c}\text { Nobasil + } \\
\text { Ekomolitan }+ \\
\text { Recycled Rubber }\end{array}$ \\
\hline 100 & 0.099 & 0.057 & 0.242 & 0.154 & 0.191 & 0.212 & 0.057 & 0.113 & 0.179 \\
\hline 125 & 0.154 & 0.081 & 0.277 & 0.185 & 0.226 & 0.212 & 0.159 & 0.154 & 0.217 \\
\hline 160 & 0.256 & 0.106 & 0.316 & 0.295 & 0.308 & 0.285 & 0.219 & 0.217 & 0.272 \\
\hline 200 & 0.361 & 0.16 & 0.361 & 0.409 & 0.39 & 0.341 & 0.299 & 0.273 & 0.333 \\
\hline 250 & 0.404 & 0.23 & 0.393 & 0.553 & 0.469 & 0.385 & 0.406 & 0.344 & 0.387 \\
\hline 315 & 0.654 & 0.344 & 0.42 & 0.686 & 0.537 & 0.427 & 0.507 & 0.402 & 0.433 \\
\hline 400 & 0.804 & 0.498 & 0.461 & 0.757 & 0.592 & 0.456 & 0.671 & 0.547 & 0.474 \\
\hline 500 & 0.873 & 0.618 & 0.494 & 0.786 & 0.622 & 0.469 & 0.716 & 0.624 & 0.505 \\
\hline 630 & 0.891 & 0.643 & 0.527 & 0.715 & 0.673 & 0.495 & 0.741 & 0.704 & 0.551 \\
\hline 800 & 0.861 & 0.562 & 0.567 & 0.609 & 0.649 & 0.479 & 0.693 & 0.777 & 0.567 \\
\hline 1000 & & 0.464 & 0.603 & 0.515 & 0.612 & 0.506 & 0.672 & & 0.648 \\
\hline 1250 & 0.789 & 0.445 & 0.636 & 0.445 & 0.549 & 0.625 & 0.689 & 0.872 & 0.628 \\
\hline 1600 & 0.801 & 0.519 & 0.663 & 0.381 & 0.472 & 0.718 & 0.779 & 0.931 & 0.654 \\
\hline 2000 & 0.849 & 0.51 & 0.689 & 0.354 & 0.397 & 0.724 & 0.898 & 0.96 & 0.693 \\
\hline 2500 & 0.873 & 0.425 & 0.7 & 0.369 & 0.387 & 0.727 & 0.985 & 0.972 & 0.716 \\
\hline 3150 & 0.873 & 0.542 & 0.739 & 0.491 & 0.463 & 0.763 & 0.989 & 0.957 & 0.782 \\
\hline 4000 & 0.889 & 0.52 & 0.791 & 0.652 & 0.616 & 0.805 & 0.947 & 0.932 & 0.813 \\
\hline 5000 & 0.902 & 0.615 & 0.795 & 0.625 & 0.645 & 0.833 & 0.928 & 0.932 & 0.84 \\
\hline 6300 & 0.923 & 0.626 & 0.83 & 0.564 & 0.568 & 0.853 & 0.929 & 0.966 & 0.862 \\
\hline
\end{tabular}


Table 2. Reduction index $\mathrm{R}$ values for materials with thickness of $60 \mathrm{~mm}$.

\begin{tabular}{|c|c|c|c|c|c|c|c|c|c|}
\hline \multirow[b]{2}{*}{$\begin{array}{c}\text { Frequency f } \\
{[\mathrm{Hz}]}\end{array}$} & \multicolumn{9}{|c|}{ Reduction Index R [dB] } \\
\hline & Ekomolitan & $\begin{array}{c}\text { Recycled } \\
\text { Rubber }\end{array}$ & Nobasil & $\begin{array}{c}\text { Recycled Rubber } \\
+ \text { Ekomolitan }+ \\
\text { Nobasil } \\
\end{array}$ & $\begin{array}{c}\text { Recycled Rubber } \\
\text { + Nobasil + } \\
\text { Ekomolitan }\end{array}$ & $\begin{array}{c}\text { Nobasil + } \\
\text { Recycled Rubber } \\
+ \text { Ekomolitan }\end{array}$ & $\begin{array}{c}\text { Ekomolitan }+ \\
\text { Recycled Rubber } \\
+ \text { Nobasil }\end{array}$ & $\begin{array}{c}\text { Ekomolitan }+ \\
\text { Nobasil }+ \\
\text { Recycled Rubber } \\
\end{array}$ & $\begin{array}{c}\text { Nobasil + } \\
\text { Ekomolitan }+ \\
\text { Recycled Rubber } \\
\end{array}$ \\
\hline 100 & 6.451 & 12.018 & 19.971 & 14.265 & 14.311 & 14.399 & 14.119 & 14.345 & 14.219 \\
\hline 125 & 6.800 & 12.245 & 19.928 & 14.278 & 14.240 & 14.481 & 14.113 & 14.392 & 14.166 \\
\hline 160 & 7.330 & 12.513 & 20.192 & 14.301 & 14.315 & 14.567 & 14.213 & 14.44 & 14.208 \\
\hline 200 & 7.853 & 12.812 & 20.700 & 14.401 & 14.410 & 14.382 & 14.347 & 14.516 & 14.259 \\
\hline 250 & 6.160 & 13.159 & 21.367 & 14.505 & 14.094 & 14.554 & 14.493 & 14.626 & 14.337 \\
\hline 315 & 7.387 & 13.557 & 22.379 & 14.870 & 14.347 & 14.786 & 14.387 & 14.825 & 14.583 \\
\hline 400 & 7.932 & 13.971 & 23.834 & 15.543 & 14.626 & 15.123 & 14.723 & 14.421 & 15.257 \\
\hline 500 & 8.533 & 14.059 & 24.815 & 15.845 & 14.816 & 15.324 & 15.086 & 14.744 & 15.375 \\
\hline 630 & 9.058 & 13.803 & 26.876 & 17.060 & 14.991 & 15.45 & 15.642 & 14.825 & 16.075 \\
\hline 800 & 9.721 & 13.554 & 29.309 & 19.336 & 16.151 & 16.526 & 16.893 & 15.901 & 17.932 \\
\hline 1000 & 10.748 & 13.027 & & & 18.201 & 18.101 & 16.220 & 16.931 & 17.652 \\
\hline 1250 & 11.896 & 13.448 & 34.956 & 21.515 & 16.690 & 15.048 & 17.916 & 18.142 & 21.949 \\
\hline 1600 & 13.270 & 15.061 & 38.039 & 25.195 & 21.604 & 20.000 & 20.140 & 21.307 & 24.455 \\
\hline 2000 & 14.703 & 16.24 & 28.289 & 26.901 & 24.655 & 23.068 & 21.898 & 23.629 & 26.307 \\
\hline 2500 & 16.513 & 15.888 & 30.917 & 29.377 & 27.707 & 25.496 & 25.671 & 27.451 & 28.086 \\
\hline 3150 & 18.585 & 17.441 & 14.019 & 32.164 & 31.809 & 29.595 & 29.266 & 31.334 & 29.326 \\
\hline 4000 & 21.221 & 18.817 & 30.334 & 33.088 & 32.173 & 30.934 & 31.729 & 31.536 & 30.796 \\
\hline 5000 & 23.828 & 21.204 & 26.772 & 36.395 & 36.148 & 34.958 & 36.218 & 35.653 & 35.193 \\
\hline 6300 & 26.176 & 28.336 & 42.359 & 43.245 & 40.895 & 38.906 & 27.802 & 37.467 & 39.318 \\
\hline
\end{tabular}


Measurements of sound absorption coefficients (a) and reduction index $\mathrm{R}$ of sandwich absorbents consisting of different combinations of two (with thickness of $20 \mathrm{~mm}, 40 \mathrm{~mm}$ and $60 \mathrm{~mm}$ ) and three (with thickness of $30 \mathrm{~mm}$ and $60 \mathrm{~mm}$ ) materials (Ekomolitan, recycled rubber, Nobasil) were also obtained. The sandwich structures are applicable for noise barrier construction (shields). The results of measurements in the frequency band ranging from $500 \mathrm{~Hz}$ to $1500 \mathrm{~Hz}$ are presented in Figures 12 and 13.

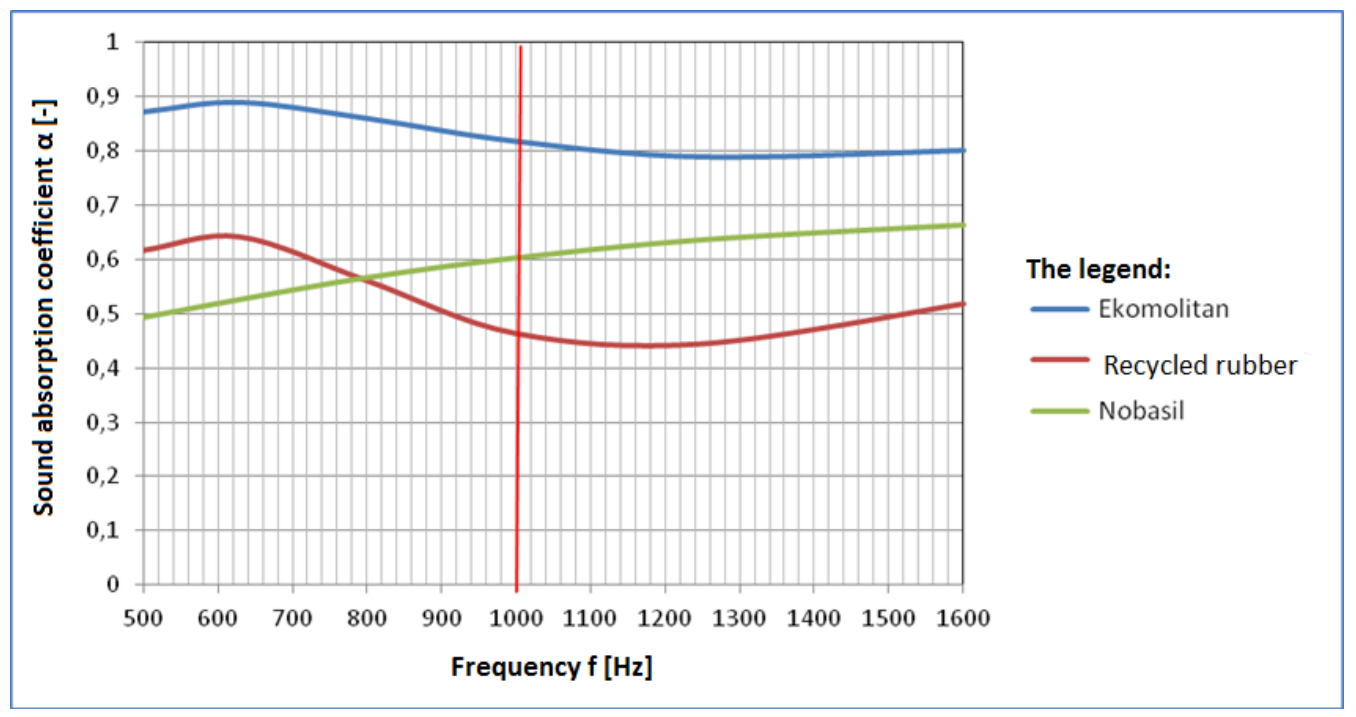

Figure 10. Sound absorption coefficient $\alpha$ (material thickness $-60 \mathrm{~mm}$ ).

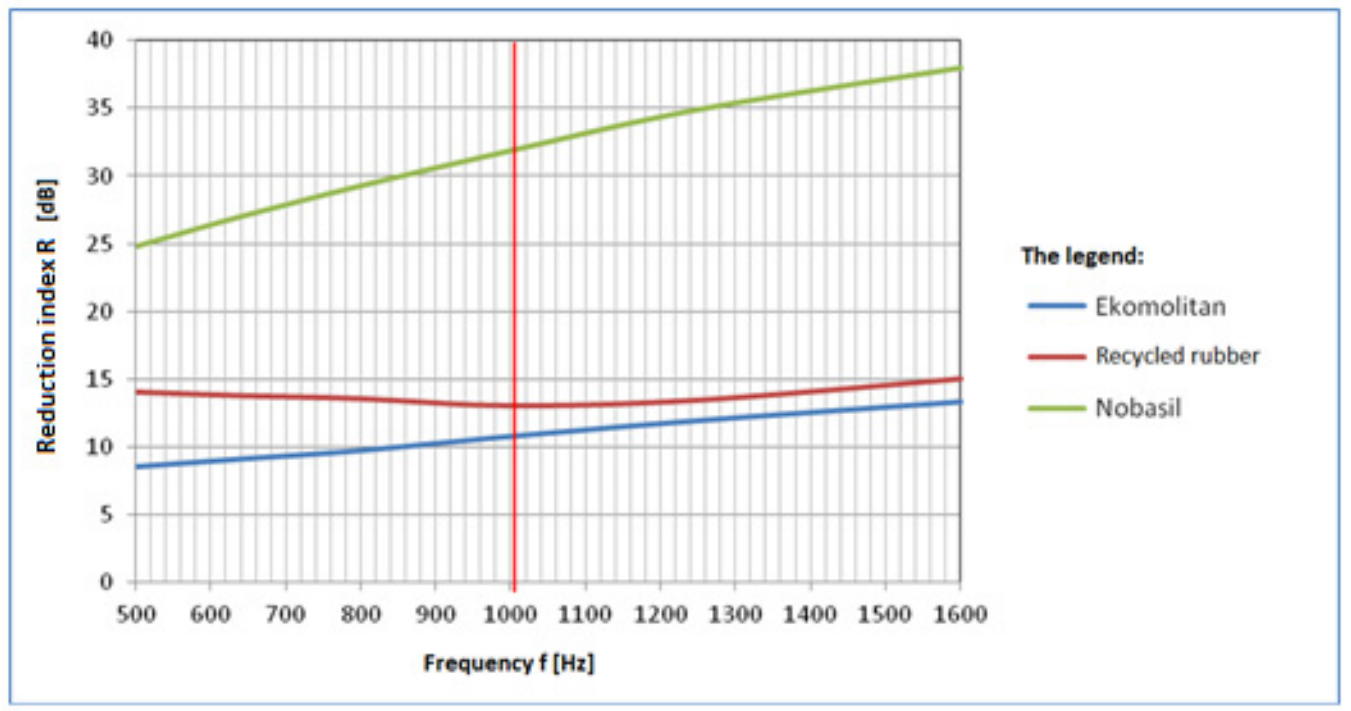

Figure 11. Reduction index R (material thickness-60 mm). 


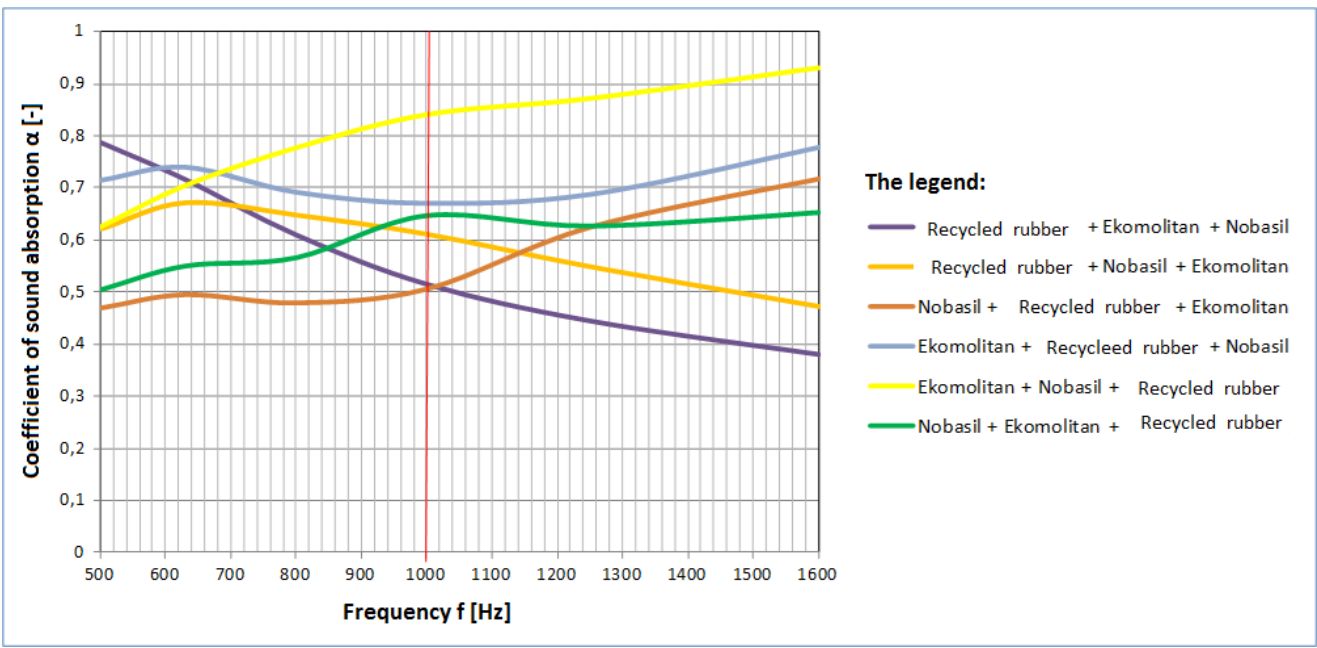

Figure 12. Sound absorption coefficient of three-layered sandwiches (total thickness of sandwiches-60 mm).

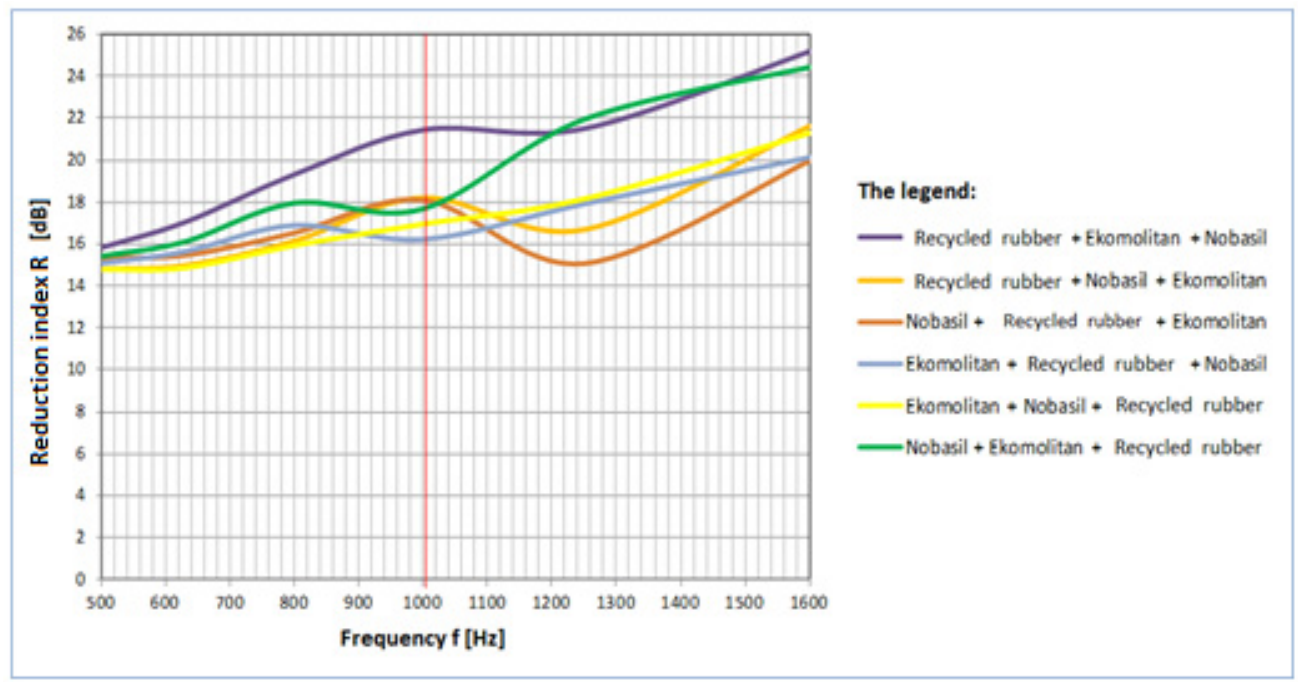

Figure 13. Reduction index $\mathrm{R}$ of two-layered sandwich absorbers (material thickness-60 mm).

\section{Conclusions}

The frequency spectrum maximum of traffic noise ranges from $500 \mathrm{~Hz}$ to $1500 \mathrm{~Hz}$, with the loudest noise produced by frequency of $1000 \mathrm{~Hz}$. Based on the measured sound absorption coefficient $(\alpha)$ values of the materials tested (Ekomolitan, recycled rubber and Nobasil) of different thicknesses $(20 \mathrm{~mm}$, $30 \mathrm{~mm}, 40 \mathrm{~mm}, 50 \mathrm{~mm}$ and $60 \mathrm{~mm}$ ) at frequencies ranging from $500 \mathrm{~Hz}$ to $1500 \mathrm{~Hz}$, and especially at frequency of $1000 \mathrm{~Hz}$, Nobasil appears to be the most suitable material at a thickness of $\geq 20 \mathrm{~mm}$, followed by Ekomolitan and finally recycled rubber. The Ekomolitan appears to be the most suitable materials at thickness of $\geq 20 \mathrm{~mm}$ followed by Nobasil, and finally recycled rubber.

It is obvious from the measured values of the sandwich absorbers' sound absorption coefficient $(\alpha)$ that the order of sandwich layers (of materials used) is important. The recommended order of sandwich (absorber) layers from the noise source at the measured materials is as follows:

(a) Two-layered sandwiches:

- $\quad$ Ekomolitan + Nobasil;

- $\quad$ Ekomolitan + Recycled rubber; and

- $\quad$ Recycled rubber + Nobasil. 
(b) Three-layered sandwiches:

- $\quad$ Ekomolitan + Nobasil + Recycled rubber.

It was established that, based on the measured values of reduction index $\mathrm{R}$ of the tested materials under consideration (Ekomolitan, recycled rubber and Nobasil), for different thicknesses $(20 \mathrm{~mm}$, $30 \mathrm{~mm}, 40 \mathrm{~mm}, 50 \mathrm{~mm}$ and $60 \mathrm{~mm}$ ) and frequencies ranging from $500 \mathrm{~Hz}$ to $1500 \mathrm{~Hz}$, the best results, for all measured thicknesses of materials, were obtained with Nobasil, followed by recycled rubber and Ekomolitan.

Based on the measured values of reduction index $\mathrm{R}$ of sandwich absorbents, it is important to state the importance of the order of individual layers of materials used in the sandwich. Note that the order of the individual layers of used sandwich materials is important. The recommended order of the sandwich (absorber) layers from the noise source of the measured materials is as follows:

(a) Two-layered sandwiches:

- $\quad$ Recycled rubber + Nobasil;

- $\quad$ Recycled rubber + Ekomolitan; and

- Nobasil + Ekomolitan.

(b) Three-layered sandwiches:

- $\quad$ Recycled rubber + Ekomolitan + Nobasil

The experimental measurements have demonstrated the suitability of selected materials (PUR foam and recycled material from tire) extracted from cars after the expiry of their life cycle in the noise barrier (shield) sandwich constructions to minimize traffic noise in the environment.

Author Contributions: B.M. responses for the scientific-research content of the article. S.L. is responsible for the correspondence, realization and preparation of an experimental part. B.A. realised and evaluated the results of the experiments. M.M. is responsible for the preparing of the tested samples and references. M.A. processed the graphic pages of the article.

Acknowledgments: This work was supported by the Slovak Research and Development Agency under Contract No. APVV-15-0327.

Conflicts of Interest: The authors declare no conflict of interest.

\section{References}

1. STN EN 1793-3: 1997. Road Noise Reduction Devices. Test Methods for Determining Acoustic Properties. Part 3: Standardized Traffic Noise Spectrum; International Organization for Standardization: Geneva, Switzerland, 1997.

2. European Environmental Agency. Noise in Europe 2014; EEA Report No. 10/2014; EEA: Luxemburg, 2014; 63p.

3. Nugent, C. Exposure to road traffic noise in Europe. In Proceedings of the CEDR Symposium Road Traffic Noise Management and Abatement, Copenhagen, Denmark, 15-16 May 2017.

4. European Environmental Agency. Quiet Areas in Europa; EEA Report No. 14/2016; The Environment Unaffecd by Noise Pollution; EEA: Luxemburg, 2016.

5. Government Regulation of Slovak Republic No. 115/2006 Coll. On Minimum Health and Safety Requirements for the Protection of Employees against Risks Related to Exposure to Noise; IURA EDITION; spol. s.r.o.: Bratislava, Slovakia, 2006.

6. Government Regulation of Slovak Republic No. 339/2006 Coll. Laying Down the Details of Permissible Values of Noise, Infrasound and Vibration and Requirements for Objectification of Noise, Infrasound and Vibrations. Council Directive 70/157/EEC of 6 February 1970 on the Approximation of the Laws of the Member States Relating to the Permissible Sound Level and the Exhaust System of Motor Vehicles. Available online: http:/ / eur-lex.europa.eu/legal-content/EN/ALL/?uri=CELEX\%3A31970L0157 (accessed on 21 November 2010). 
7. Usage, Quality and System of Soundproofing Walls (In Slovak). Available online: http:/ /www.telecom.gov. sk/files/doprava/dopinfra/cesinfra/tech_predpisy/2006/tp_08_2006_pdf (accessed on 1 February 2011).

8. Matel, F.; Ochocová, R.; Badida, M.; Lumnitzer, E. Patent No. 1/288237 Non-Flammable Treatment of Sound-Absorbing Elements from Recycled Carpets and Rubbers. (In Slovak: Nehorl'avá Úprava Zvukovopohltivých Prokov z Recyklovaných Autoplášt'ov a Gúm); Úrad Priemyselného Vlastníctva Slovenskej Republiky: Banská Bystrica, Slovakia, 2010.

9. Badida, M.; Lumnitzer, E.; Bartko, L. Possibilities of Reducing Traffic Noise (In Slovak); Elfa Košice: Sever, Slovakia, 2011; p. 303, ISBN 978-80-8086-181-0.

10. Badida, M.; Badidová, A.; Sobotová, L.; Dzuro, T. The research of acoustic properties of absorbers on the aluminum foam. Sci. Lett. Acad. Soc. Michal Baludansky 2016, 6A, 2-7.

11. Badida, M.; Sobotová, L.; Kraliková, R.; Badidová, A.; Hurajt, M.; Konkoly, T. Determination of optimal production volume responding environmental criteria. MM Sci. 2016, 2016, 1118-1120. [CrossRef]

12. Badidová, A.; Moravec, M.; Badida, M.; Sobotová, L. Evaluation of sound quality in interior of automobile by psychoacoustical evaluation methods. In Proceedings of the ICEEE 2016, Budapest, Hungary, 17-19 November 2016.

13. Badida, M.; Sobotová, L.; Borošová, L.; Liptai, P.; Moravec, M. The research of acoustic properties of sandwich absorbers on the aluminium foam base. In Proceedings of the In-Tech 2015, Rijeka, Croatia, 9-11 September 2015; pp. 315-318.

14. Badida, M.; Liptai, P. The use of recyclables from car wrecks in the design of noise abatement measures in quarries (In Slovak). In Proceedings of the TOP 2010, Engineering for Environment Protection, Bratislava, Slovakia, 15-17 June 2010; pp. 251-256.

15. Badidová, A.; Sobotová, L. Analysis of sound quality assessment methods in automobiles (In Slovak). In Novus Scientia; TU: Košice, Slovakia, 2017; pp. 1-5, ISBN 978-80-553-3080-8.

16. Neubergová, K. Ecological Aspects of Transport (In Czech); ČVUT: Praha, Czech Republic, 2005; 163p, ISBN 80-01-003131-4.

17. Staciu, M.D.; Curtu, I.; Cosereaunu, C.; Lica, D.; Nastac, S. Research regardingacoustical properties of recycled composities. In Proceedings of the 8th International DAAAM Baltic Conference Industrial Engineering, Talin, Estonia, 19-21 April 2012; pp. 1-6.

18. Curtu, I.; Stanciu, M.D.; Coereanu, C.; Ovidiu, V. Assesment of Acoustic of Biodegradable Composite Materials. J. Mater. Plast. 2012, 41, 68-73.

19. Del Rey, R.; Alba, J.; Arenas, J.P.; Sanchis, V. Sound absorbing materials made of recycled polyurethane foam. In Proceedings of the Inter-Noise 2011, Osaka, Japan, 4-7 September 2011; pp. 1-6.

20. STN EN ISO 10534-1: 1996. Acoustics-Determination of Sound Absorption Coefficient and Acoustic Impedance in Impedance Tubes_-Part 1: Method of Using the Standing Wave; International Organization for Standardization: Geneva, Switzerland, 1996.

21. STN EN ISO 10534-2: 1998. Acoustics-Determination of Sound Absorption Coefficient and Acoustic Impedance in Impedance Tubes-Part 2: Method of Transformation Function; International Organization for Standardization: Geneva, Switzerland, 1998.

22. STN ISO 10847: 2000. Acoustics_Determination of Insertion Loss of External Noise Barriers of All Types at the Place of Permanent Storage (In Situ); International Organization for Standardization: Geneva, Switzerland, 2000.

23. STN EN 1793-1: 1997. Road Noise Reduction Devices. Test Methods for Determining Acoustic Properties. Part 1: Determination of Sound Absorption; International Organization for Standardization: Geneva, Switzerland, 1997.

24. STN EN 1793-2: 1997. Road Noise Reduction Devices. Test Methods for Determining Acoustic Properties. Part 2: Determination of Airborne Sound; International Organization for Standardization: Geneva, Switzerland, 1997.

(C) 2018 by the authors. Licensee MDPI, Basel, Switzerland. This article is an open access article distributed under the terms and conditions of the Creative Commons Attribution (CC BY) license (http:/ / creativecommons.org/licenses/by/4.0/). 